DOI 10.37882/2223-2982.2021.02.13

\title{
ПОЛИТИКО-ВОСПИТАТЕЛЬНАЯ РАБОТА И ВОИНСКАЯ ДИСЦИПЛИНА В РЯЗАНСКОМ ПУЛЕМЁТНОМ УЧИЛИЩЕ В 1942 ГОДУ
}

\section{POLITICAL EDUCATION AND MILITARY DISCIPLINE AT RYAZAN MACHINE-GUN ACADEMY IN 1942}

\section{G. Larin}

Summary: This article concentrates on political education and military discipline in Ryazan Machine Gun Academy in 1942.

It addresses the questions related to establishment and operation of local parties and komsomol organizations of the Academy.

To achieve the goals of this article, the denunciations of the Academy's political department were analyzed. The examples are given to illustrate the punishment administration and personnel development methods.

Keywords: military academy, political education, military discipline, local parties and komsomol organizations, political denunciation, officer, cadet.

\author{
Ларин Геннадий Владимирович \\ Аспирант, Рязанский государственный \\ университет имени С.А. Есенина \\ larin191975@yandex.ru
}

Аннотация: (татья посвящена политико-воспитательной работе и воинской дисциплине в Рязанском пулемётном училище в 1942 году.

Рассмотрены вопросы создания и функционирования первичных партийных и комсомольских организаций училища. Проанализированы донесения политического отдела училища.

Приведены примеры дисциплинарной практики, методов и форм воспитания военнослужащих за указанный период.

Ключевые слова: военное училище, политико-воспитательная работа, воинская дисциплина, первичные партийные и комсомольские организации, политическое донесение, офицер, курсант.
B годы Великой Отечественной войны уделялось большое значение подготовке беззаветно преданных Родине командирских кадров. Одним из критериев воспитания будущих офицеров стала усиленная политико-воспитательная работа, проводимая во время их обучения. В тяжёлых бытовых условиях и в сжатые сроки в военных училищах была развёрнута интенсивная деятельность по снижению преступлений и происшествий и улучшению воинской дисциплины.

Из семи военных училищ, дислоцировавшихся в годы Великой Отечественной войны в Рязанской области, для изучения данных вопросов было выбрано Рязанское пулемётное училище. Такой выбор обусловлен рядом причин. Во-первых, данное училище было максимально удалено от областного центра по сравнению с остальными действовавшими в области военными училищами, что вызывало дополнительные трудности в снабжении и в ряде других вопросов. Во-вторых, оно являлось единственным из них военным училищем, которое ни разу не передислоцировалось вплоть до момента своего расформирования в 1945 году. Временной отрезок также был выбран по ряду причин: в 1942 году началось формирование Рязанского пулемётного училища, следовательно, все самые сложные процессы по налаживанию работы выпали именно на этот период. 1942-й год для СССР был не менее трагичным, чем первый год войны и ситуация на фронтах была крайне тяжёлой. Кроме того, в 1942-м году были изданы: приказ Народного комиссара обороны Союза ССР от 28 июля 1942 года № 227 «О мерах по укреплению дисциплины в Красной Армии и запрещении самовольного отхода с боевых позиций», более известный в простонародье как «Ни шагу назад», приказ Народного комиссара обороны Союза ССР от 9 октября 1942 года №307 «Об установлении единоначалия и упразднении института военных комиссаров в Красной армии», боевой устав пехоты Красной Армии в двух частях (БУП-42), утверждённый и введённый в действие приказом Народного комиссара обороны Союза ССР от 9 ноября 1942 года № 347 и ряд других приказов и распоряжений. Эти документы для многих военнослужащих стали судьбоносными.

В рамках данной работы была поставлена цель: изучить политико-воспитательную работу и воинскую дисциплину в училище за указанный промежуток времени.

Для достижения данной цели был определен ряд задач:

- установить, какие документы разрабатывались и велись в училище при ведении политико-воспитательной работы и какие моменты в них отображались;

- изучить вопросы воинской дисциплины в училище; 
- осветить формы и методы воспитания военнослужащих.

Для решения поставленных задач был определён круг необходимых архивных материалов и выстроена методология их исследования.

В Центральном архиве Министерства обороны РФ (далее ЦАМО) были в полном объёме установлены документы, отображающие функционирование Рязанского пулемётного училища за весь период его существования, в том числе те, в которых отображены политиковоспитательная работа и воинская дисциплина. К документам, позволяющим изучить вышеуказанные вопросы как данного, так и других военных училищ, относятся:

- Планы боевой и политической подготовки;

- Акты инспектирования и доклады о состоянии боевой и политической подготовки;

- Приказы по училищу о состоянии боевой и политической подготовки, воинской дисциплины;

- Приказы по училищу и Касимовскому гарнизону о состоянии боевой и политической подготовки;

- Приказы по училищу об аттестации офицерского состава, воинской дисциплине и дисциплинарной практики;

- Книги учёта чрезвычайных происшествий;

- Донесения политического отдела училища;

- Протоколы собраний первичных партийных организаций управления училища;

- Протоколы собраний первичных партийных организаций батальонов;

- Протоколы собраний первичных комсомольских организаций батальонов;

- Протоколы собраний партийного и комсомольского активов училища.

- Письма выпускников с фронта.

- Ведомости сбора денег курсантами на создание вооружения.

Помимо материалов ЦАМО были изучены фонды Муниципального бюджетного учреждения культуры «Касимовский историко-культурный музей-заповедник».

Таким образом можно утверждать, что в результате проведенного исследования в научный оборот введены сведения, которые ранее нигде не представлялись. Выдержки из наиболее интересных с познавательной точки зрения документов, отображающих цель и решающих задачи, поставленные в данной статье, приведены в ней.

Рязанское пулемётное училище сформировано в период с 10 по 28 августа 1942 года и до самого расфор- мирования находилось в городе Касимове Рязанской области. Расформировано 1 апреля 1945 года. ${ }^{1}$

В политдонесении от 26 августа 1942 года комиссара Касимовского (согласно первоисточнику) пулемётного училища батальонного комиссара Ватутина на имя начальника политического управления МВО бригадного комиссара Миронова указывалось:

Целый ряд вопросов, связанных с организацией училища, командование разрешает с партийными, советскими и другими организациями, которые оказывают необходимую помощь в организации училища;

Кадры политсостава прибывают в училище чрезвычайно медленно. До сих пор в училище не прибыли комиссары батальонов - 3 человека, ответственные секретари партийных бюро батальонов - 4 человека, ответственные секретари бюро ВЛКСМ - 5 человек, помощник начальника политотдела училища по комсомолу;

На 25 августа 1942 года в училище прибыло командно-политического состава 153 человека. Из них политсостава 16 человек, включая сюда преподавателей социально-экономического цикла;

Партийность командного и начальствующего состава (не считая политработников): коммунистов 27, комсомольцев 45, беспартийных $65 .^{2}$

В батальонах проводится ежедневная политинформация. С 26 августа 1942 года выходят боевые листки по взводам и ротам. По батальонам газеты будут выходить, как только будут оформлены партийные и комсомольские организации. Каждый батальон начал получать центральные газеты: «Правда» - 12, «Красная звезда» - 8, «Красный воин» - 14, «Комсомольская правда» - 2. Кроме того с 1-го сентября будут областная и районная газеты. Лимит на них ещё не получен от Рязанского обкома ВКП/б/. Дано задание комиссарам батальонов по проведению бесед и выступлений участников боёв фронта Отечественной войны. Политотдел проводит индивидуальную беседу с фронтовиками, ведёт запись их с целью использования среди курсантов для того, чтобы была возможность поделиться с ними боевым опытом.

Происходит разучивание боевых песен среди курсантов. Началась организационная работа по созданию кружков художественной самодеятельности. ${ }^{3}$

Выборы партийных органов намечаются на 5-е сентября 1942 года. Выборы комсомольских органов будут

ЦАМО. Ф. 60067. (Рязанское пулемётное училище) Краткая историческая справка.

ЦАМО. Ф. 60067. Оп. 35134. Д. 22. Л. 1

Там же, Л. 2. 
проведены 15-18 сентября. В этот же период будут созданы батальонные и ротные редколлегии.

В данном документе был сделан вывод о том, что моральное состояние командного и политического состава и курсантов хорошее. Командование училища имеет всё необходимое в своём распоряжении для начала учёбы. Имеется материальная база, кадры. Организационный период заканчивается. С 9-го сентября 1942 года пулемётное училище сможет приступить к нормальным учебным занятиям. ${ }^{4}$

В данном политдонесении подробно изложено о большом объёме проделанной работы за чуть более двухнедельный срок с момента формирования училища. Рассказано о трудностях укомплектования политсоставом, о мероприятиях, проводимых в курсантских подразделениях.

В Рязанское пулемётное училище для службы на первичных офицерских должностях направлялись выпускники других военных училищ. Вызывает интерес запрос старшего батальонного комиссара Антонова заместителя начальника Московского пулемётно-миномётного училища, дислоцировавшегося в Хлебниково Московской области на имя заместителя начальника Касимовского (согласно первоисточнику) пулемётного училища по политической части. В нём говорилось, что 4 сентября 1942 года в ваше училище были направлены для прохождения дальнейшей службы на должности командиров пулемётных взводов лейтенанты в количестве 10 человек из Московского пулемётно-миномётного училища. Далее, старший батальонный комиссар Антонов убедительно просил сообщить, как проходят службу их питомцы, прошедшие 6-ти месячный срок обучения в их училище, справляются с работой, какие должности занимают, на каком уровне их подразделения, как они выглядят по сравнению с другими командирами, прибывшими из других училищ. Просил предоставить данную информацию по подробнее и поскорее. ${ }^{5}$ Данный документ свидетельствует о том, что несмотря на тяжёлое время, со стороны командования военных училищ шёл о выпускниках постоянный сбор и обмен информацией, которая накапливалась, анализировалась и использовалась в дальнейшем в воспитании и обучении курсантов.

Как указывалось выше, создание первичной партийной организации училища планировалось на 5-е сентября. Исходя из того, что протокол №1 общего собрания данной организации датирован 6-м сентября 1942 года, можно сделать вывод о том, что данное мероприятие было осуществлено точно в указанный срок. В протоколе №1 собрания штабной первичной парторганизации
Касимовского (согласно первоисточнику) пулемётного училища от 6 сентября 1942 года на повестке дня стояли вопросы:

1. О задачах парторганизации на дальнейший период работы училища (доклад полковника Свищева);

\section{2. Выборы партбюро штаба.}

В своём докладе товарищ Свищев дал установку и ставил конкретные задачи перед парторганизацией штаба по развёртыванию его работы, а также его отделов. Он отмечал слабость контроля в подразделениях за ходом боевой и политической подготовки. Освещая процесс комплектования училища командно-начальствующим, курсантским и вольнонаёмным составами докладчик обратил особое внимание на усиление политической бдительности и на сохранение военной тайны, в особенности со стороны вольнонаёмного состава. В заключении товарищ Свищев призвал парторганизации по-боевому развернуть работу на основе социалистического соревнования.

\section{Далее слово было предоставлено выступающим.}

Выступающий товарищ Терентьев остановился на подготовке из курсантов волевых командиров, способных выполнить любой приказ Родины.

Выступающий товарищ Зырянов говорил о проведении в жизнь приказов товарища Сталина № 130 и № 227. Он указал, что комсомольская прослойка в подразделениях хорошая и на неё можно опереться при подготовке курсантского состава к их будущей работе в качестве командиров РККА.

Выступающий Токмалаев отметил, что в области политподготовки очередной задачей перед преподавателями является тщательная работа над конспектами, внесение в преподавание элементов агитации и нетерпимости нарушения воинской дисциплины и порядка во время занятий. Он отметил наличие среди некоторой части курсантов непонимание существа боевого товарищества и подмены его обывательским товариществом.

Начальник политотдела училища Ватутин отметил: «Нам надо поставить так работу по боевой и политической подготовке, чтобы у нас была железная воинская дисциплина во всех звеньях училища, чтобы приказы штаба МВО и командования, училищем выполнялись точно и в срок и чтобы всё училище было в постоянной мобилизационной готовности идти в любой момент в бой с врагом».

\footnotetext{
Там же, Л. 3.

5 ЦАМО.Ф. 60067. Оп. 35135. Д. 4. Л. 243.
} 
В партбюро штаба единогласно были выбраны Комаров, Киладзе, Токмалаев, Седов, Зарывалов. ${ }^{6}$

Ежемесячно, вплоть до момента расформирования училища, начальником политотдела училища или его заместителем предоставлялись политдонесения в политическое управление Московского военного округа. В них отображались вопросы, касаемые воинской дисциплины, преступлений, происшествий, процесса обучения, а также изучения самых значимых руководящих документов.

Так, в политдонесении от 18 сентября 1942 года заместителя начальника политотдела училища батальонного комиссара Заворотищева начальнику политуправления МВО бригадному комиссару Миронову докладывалось о ходе выполнения приказа Народного комиссара обороны товарища Сталина № 227 по Рязанскому пулемётному училищу нижеследующая информация. Приказ товарища Сталина № 227 всем командно-политическим составом училища и курсантами воспринят как основной военно-политический документ, определяющий задачи Красной Армии, партийных и комсомольских организаций Красной Армии на данный период - период суровой опасности для Родины, когда на поле боя дисциплина и военная выучка Красной Армии обеспечат разгром немецко-фашистских войск. Работа по изучению и проведению в жизнь приказа НКО № 227 оказала действенные результаты на повышение боевой и политической подготовки. Так, во 2-м батальоне 5-я рота имеет успеваемость в целом по роте - 4,08, 8-я рота - 4,07. В батальоне насчитывается 189 курсантов, которые учатся только на хорошо и отлично. В 1-м батальоне 88 курсантов имеют хорошие и отличные отметки по боевой и политической подготовке. В этом же батальоне хорошо организована помощь отстающим. Все курсанты и командиры включались в социалистическое соревнование им. 25-й годовщины Октября. Уже сейчас имеются положительные результаты соревнования. 2-я рота /командир роты лейтенант Иванчук/ имеет 100\% успеваемости по тактике, огневой подготовке, топографии и уставам. Командиры-комсомольцы Иванчук, Закурдаев, Роголев, Лебедев, Хатунский в соцсоревновании идут в первых рядах. Курсанты Жилин, Утробин, Колосов за усиленную учёбу получили благодарности. Во 2-м батальоне круглых отличников насчитывается 11 человек. Можно приводить много положительных примеров об успеваемости курсантов, но достаточно этих, которые ясно показывают стремление курсантов и командиров в кротчайший срок подготовить полноценного командира Красной Армии.

В целом по училищу улучшилась дисциплина среди командно-политического, а также и среди курсантского составов. Но ещё до сего времени имеют место нарушения воинской дисциплины. Имеют место случаи попыток невыполнения приказаний. Курсант 3-го батальона 11 роты 4 взвода Запрудный не выполнил приказание, получил три наряда вне очереди. Курсант 12 роты, член ВЛКСМ Матрусов получил арест на 3-е суток за плохой уход за оружием /ржавая винтовка/.

Привлекается к комсомольской ответственности сержант товарищ Вакуновский В. А. 11 рота, член ВЛКСМ, участник Отечественной войны за пьянство получил 5 суток ареста, по комсомольской линии получил строгий выговор. Старшина 19 роты Клешков за приход в столовую батальона в пьяном виде отстранён от должности. Сейчас обнаружено, что у него в подразделении нехватка курсантского белья и мыла. Помощник командира 1 взвода 18 роты, сержант Баталов 25 сентября 1942 года бросил взвод, занял у 6 курсантов деньги в сумме 520 рублей, продал казённое белье, мыло курсантов взвода, напился пьяным и даже с вином явился в подразделение. Посажен на гауптвахту. Причём, сигнал о том, что Баталов уходил был известен военкому старшему политруку Малышеву, но он не принял соответствующих мер. Лейтенант Берстнев /командир 3 взвода 13 роты/ дважды совершил самостоятельную отлучку, вторую продолжительностью - 8 часов. Благодаря плохой организации учёбы взвод плетётся в хвосте по успеваемости. 22 сентября 1942 года бюро ВЛКСМ исключило Берстнева из членов ВЛКСМ.

На всех нарушителей дисциплины наложены дисциплинарные взыскания. Они привлекаются к товарищеским судам, обсуждению на партийных и комсомольских собраниях, вплоть до исключения из партийных и комсомольских рядов.

Несмотря на вышеуказанные случаи нарушения воинской дисциплины, в целом по училищу приказ НКО № 227 командно-политическим, а также и курсантским составами серьезно осознан и безукоризненно выполняется. ${ }^{8}$

К различного рода ответственности привлекались не только военнослужащие училища, но и гражданский персонал, в том числе женщины. Так, в приказе № 60 по Рязанскому пулемётному училищу от 14 октября 1942 года сказано, что на основании рапорта заместителя начальника политического отдела училища машинистку политического отдела Тахкачееву за самовольный уход с работы 7 октября, сего числа привлечь к уголовной ответственности через прокуратуру Касимовского района

\footnotetext{
6 ЦАМО. Ф. 60067. Оп. 35134. Д. 23. Л. 1-3 с об.

7 ЦАМО. Ф. 60067. Оп. 35134. Д. 22. Л. 11, 12.

8 ЦАМО.Ф. 60067. Оп. 35134. Д. 22. Л. 1206.
} 
и из списков училища исключить. ${ }^{9}$

За упущения в работе наказаниям подвергался офицерский состав. В приказе по училищу № 61 от 15 октября 1942 года за нарушение светомаскировки начальником училища полковником Свищевым были наложены дисциплинарные взыскания:

1. Командиру 5-го батальона старшему лейтенанту Комарову объявлен выговор;

2. Командир 18-й роты лейтенант Белищев арестован на 5 суток с удержанием 50\% зарплаты за каждый день ареста;

3. Командир 1-го взвода 19-й роты лейтенант Назаренко арестован на 3 суток с удержанием 50\% зарплаты за каждый день ареста;

4. Дежурному по кухне и столовой №1 лейтенанту Торопину (2-й батальон) объявлен выговор;

5. Помощнику по МТО интенданту 3-го ранга Терентьеву за необеспечение кухни и столовой №1 светомаскировкой поставлено на вид. ${ }^{10}$

Функционирование училища продолжалось и далее в контексте приказа № 227. В политдонесении от 20 октября 1942 года заместитель начальника политотдела училища батальонный комиссар Заворотищев начальнику политуправления МВО бригадному комиссару Миронову о ходе выполнения данного приказа сообщал:

Политотдел продолжает широко проводить агитационно-пропагандистскую работу по разъяснению и доведению личному составу приказа товарища Сталина № 227.

Среди курсантского состава по этому вопросу проводятся ежедневные беседы. Кроме того, по всем подразделениям проведены беседы на тему «Военно-политическое значение приказа товарища Сталина № 227».

Результатом проводимой агитационно-пропагандистской работы среди личного состава является улучшение воинской дисциплины. Если в начале сентября в училище имелось несколько случаев сна курсантов на посту, то в октябре таких случаев не было. Падает количество нарушений воинской дисциплины. За первую половину сентября было - 64 случая нарушения, за первую половину октября они снизились до 50 случаев. На всех нарушителей воинской дисциплины наложено дисциплинарное взыскание. Улучшилась боевая и политическая подготовка курсантов. Так, например успеваемость курсантов по училищу за сентябрь выразилась 92,3\%, за первую половину октября успеваемость возросла до 96,7\%. Было отличников 426, стало 612. Курсантов с плохими отметками было 190, стало 82.

По училищу насчитывается несколько подразделений, имеющих 100\% успеваемость по боевой и политической подготовке. Например, 1-я рота имеет успеваемость 100\% - командиром этой роты является лейтенант Востриков, кандидат в ВКП/б/.

Лучшими ротами по выполнению первого упражнения стрельбы из винтовки являются: 5-я рота (командир лейтенант Солдатенко); 7-я рота (командир младший лейтенант Евсеев). Курсанты этих рот выполнили упражнения на хорошо и отлично - 70\% и 30\% на посредственHo.

Прошедшее отрядное тактическое учение 10 и 13 октября выявило небывалый наступательный порыв всего личного состава.

Выявленные на отрядных учениях недостатки в отработке одиночного бойца сейчас командованием училища устраняются. Характер этих недостатков заключается в том, что многие курсанты плохо маскировались и самоокапывались, делали длинные перебежки, нарушалась связь командиров взводов с командирами рот и командиров рот с батальонным командным пунктом.

Вся партийно-политическая работа проводится политотделом, партийными и комсомольскими организациями и подчинена задачам выполнениям приказа товарища Сталина. ${ }^{11}$

В цифровой сводке о случаях чрезвычайных происшествий за октябрь 1942 года в училище зафиксировано 4 факта дезертирства военнослужащих. Среди которых 3 человека совершили данное преступление из числа рядового состава и 1 из офицерского. Один военнослужащий являлся членом ВЛКСМ, трое были беспартийными. Трое в возрасте до 25 лет, один в возрасте от 25 до 40 лет. Трое по национальности русские, один чуваш. Кроме того, в октябре имели место чрезвычайные происшествия, представленные в таблице №1, информация дана в сравнении с предыдущим месяцем.

9 ЦАМО.Ф. 60067. Оп. 35135. Д. 7. Л. 58.

10 Там же, Л. 59об, 60.

11 Там же, Л. 5906, 60. 
Таблица 1. Чрезвычайные происшествия в Рязанском пулемётном училище в сентябре и октябре 1942 года

\begin{tabular}{|l|c|c|}
\multicolumn{1}{|c|}{$\begin{array}{c}\text { Вид чрезвычайного } \\
\text { происшествия }\end{array}$} & Сентябрь 1942 г. & Октябрь 1942 г. \\
\hline $\begin{array}{l}\text { Несчастный случай, вызвавший } \\
\text { смерть военнослужащего }\end{array}$ & 0 & 1 \\
\hline Сон на посту, уход споста & 8 & 0 \\
\hline Пьянство и дебош & 3 & 9 \\
\hline Итого: & 11 & 10 \\
\hline
\end{tabular}

(ЦАМО. Ф. 60067. Оп. 35134. Д. 22. Л. 31)

Продолжали иметь место проступки, совершённые офицерским составом, о чём излагается в двух нижеследующих приказах по училищу.

На основании материалов дознания был издан приказ № 95 по Рязанскому пулемётному училищу от 17 ноября 1942 года. В нём говорилось, что были похищены дрова, принадлежащие Касимосвскому затону и перенесены они силами курсантов на частную квартиру командира 2 взвода 5 роты лейтенанта Демидова. За что он был арестован на 5 суток с удержанием 50\% зарплаты за каждый день ареста. Стоимость дров должна была быть возмещена затону. ${ }^{12}$

В приказе № 96 по Рязанскому пулемётному училищу от 18 ноября 1942 года сказано, что за незнание устава караульной службы, командир 1 взвода 17 роты лейтенант Молчанов арестован на 5 суток с удержанием $50 \%$ зарплаты за каждый день ареста. ${ }^{13}$

Если второй приказ говорит о явной неподготовленности офицера и упущении его по службе, то из содержания первого приказа в очередной раз становится ясно, что условия размещения офицерского состава и снабжения его топливом были на крайне низком уровне.

В подтверждении этих слов интересен ответ на директиву начальника политического управления МBO бригадного комиссара Миронова № 59с от 2 декабря 1942 года. Начальник политического отдела Рязанского пулемётного училища батальонный комиссар Ватутин докладывал о ниже следующем:

Ряд важнейших вопросов подготовки училища к зиме по вине помощника начальника училища по материально-техническому обеспечению интенданта III ранга товарища Терентьева на сегодняшний день являются неразрешенными.
Курсанты зимним обмундированием не обеспечены, что отрицательно влияет на ход боевой и политической подготовки. Уже сейчас имеются неоднократные случаи заболевания гриппом и воспалением лёгких. Из-за отсутствия сапожной мази обувь приходит в негодность, а открытая починочная мастерская требуемый ремонт обуви не обеспечивает. Сушилками обуви, портянками и обмундированием училище не обеспечивается.

Прачечная открыта, количество стираемого белья может обеспечить своевременную его смену, но качество стирки явно неудовлетворительное. В результате этого мы имеем неоднократные случаи вшивости курсантов.

Из-за плохой организации работы курсантских столовых часто имеют место опоздания подразделений на занятия. В столовых грязно, а санчасть, призванная привести в настоящий санитарный порядок столовые решительных мер к устранению антисанитарии, не принимает. Дрова в количестве свыше 1000 м³ заготовлены, но не вывезены, а поэтому отопление из-за необеспечения подвоза дров /нехватка саней/ идёт неравномерно, с перебоями.

Командный состав училища зимним обмундированием не обеспечен. Особенно плохо обстоит дело с организацией питания командного состава.

Ввиду отсутствия военторга питание вольнонаемного состава, а также семей комсостава никак не организовано. Заместитель начальника Рязанского военторга товарищ Сучкова обещала отпускать продукты для питания вольнонаемного состава и семей комсостава училища, но до сего времени продукты не отпускаются. ${ }^{14}$

Исходя из вышеизложенного делаем вывод, что в училище на момент начала зимы испытывало большие материально-бытовые трудности. Проблемы возникли с разного рода снабжением как курсантов, так и офицеров с членами их семей. Всё это несомненно негативно сказывалось на моральном состоянии личного состава училища и накладывало отпечаток на выполнение им своих должностных обязанностей.

Одним из главных руководящих документов РККА, принятых в 1942 году, стал приказ Народного комиссара обороны Союза ССР от 9 октября 1942 года № 307 «О6 установлении единоначалия и упразднении института военных комиссаров в Красной армии». Данный документ, в отличии от приказа НКО СССР № 227, вышел в свет на момент функционирования училища. Следова-

\footnotetext{
12 ЦАМО.Ф. 60067. Оп. 35135. Д. 7. Л. 90.

13 Там же, Л. 9106.

14 ЦАМО. Ф. 60067. Оп. 35134. Д. 22. Л. 46.
} 
тельно, определенный опыт внедрения второго приказа у офицеров по их прежнему месту службы уже был, а внедрение первого в жизнь стало делом новым. Итоги этой работы представлены процитированным ниже политдонесением.

Заместитель начальника политического отдела Рязанского пулемётного училища батальонный комиссар Заворотищев в декабре 1942 года на имя начальника политического управления МВО бригадного комиссара Миронова своим донесением о выполнении приказа НКО № 307 от 9 сентября 1942 года сообщал о том, что как только он был опубликован, было созвано совещание военкомов батальонов и секретарей партийных организаций. На этом совещании был поставлен вопрос о практическом применении приказа в училище и об усилении партийно-политической работы.

На следующий день во всех подразделениях состоялись собрания командного состава по вопросу доведения и разъяснения этого приказа.

Среди курсантского состава приказ НКО № 307 был зачитан и разъяснён политработниками и командирами.

После всей этой работы был созван партийный актив училища, который обсудил вопрос «О перестройке партийно-политической работы в связи с приказом НКО № 307».

После проведения этих организационных и разъяснительных мероприятий по приказу, партийно-политическая работа значительно усилилась. Это усилие выразилось в том, что повысился интерес командного состава к политическим лекциям и докладам, многие командиры сразу включились в политическую работу. Они стали делать доклады, проводить сами политинформации и политбеседы. Кроме этого, стали помогать агитаторам своих подразделений в выборе тем и подборе материала для бесед, принимали активное участие в выпуске стенной печати и в организации художественной самодеятельности. Такие командиры как старший лейтенант Тарасевич, беспартийный /командир 4-го батальона/, лейтенант Таглин /командир 14-й роты/, лейтенант Зверев /командир 16-й роты/, старший лейтенант Савиров кандидат ВКП/б/ /командир 2-го батальона/, лейтенант Космацкий член ВЛКСМ /заместитель командира 2-го батальона/, лейтенант Кондрусов беспартийный /заместитель командира 8-й роты/ и многие другие, которые раньше не занимались политической работой, в данное время непосредственно ведут политическую работу, выступают с докладами, проводят политбеседы и политинформации.

В настоящее время большинство командного состава принимает непосредственное участие в политической жизни своих подразделений. Но в училище ещё находятся многие командиры, которые занимаются боевой подготовкой, но политической работой не занимаются. К таким командирам относятся - лейтенант Герасимов / заместитель командира 17-й роты/, лейтенант Терёхин / заместитель командира 18-й роты/, старший лейтенант Любимов /командир 9-й роты/, лейтенант Горюнов /командир 4-го взвода 10-й роты/, лейтенанты Витковский, Липшиц, Ватимов и другие.

Все командиры, за исключением единиц, свою роль единоначальника поняли и проводят это на практике. Но имеются такие факты, которые граничат с невыполнением отдельными командирами функций единоначальника. Так, например, лейтенант Любимов командир 9-й роты дал распоряжение командирам взводов о подготовке к стрельбам, но выполнение своего приказа не проверил. На другой день, когда его подразделение вышло на стрельбище, то оказалось, что пулемёты не были подготовлены до стрельб и не оказалось патронов. В результате упражнение из них началось вместо 8:00 в 11:00, тем самым занятие в большей степени было сорвано изза их неподготовленности для стрельбы. Не подготовился к проведению тактических занятий с командирами командир 3-го батальона Катышев. Начальник училища полковник Свищев отстранил его от занятий и вынужден был сам проводить занятия с офицерами 3-го батальона несмотря на ряд недостатков в проведении приказа НКО № 307. Тем не менее партийно-политическая работа значительно улучшилась, партийные и комсомольские собрания проходят активнее и, они решают актуальные вопросы своих подразделений. Как например: о ходе своей подготовки, сохранения и сбережения оружия, о выполнении приказов Наркома обороны товарища Сталина, об укреплении воинской дисциплины. Организовано стали проходить семинары ораторов. Регулярно стали проводить лекции и доклады, как для командиров, так и для курсантов. Систематически проходят политинформации. Оживился выпуск боевых листков и стенгазет.

Хорошо была организована художественная самодеятельность 1-го и 5-го батальонов. По примеру этих батальонов работа художественной самодеятельности улучшается и в других батальонах.

Нарушение партийной дисциплины коммунистами и комсомольцами за первую половину декабря не имело место в училище. Также не было нарушений и воинской дисциплины как коммунистами, так и комсомольцами.

Общее количество дисциплинарных нарушений снизилось с 92 случаев в октябре до 76 случаев в ноябре.

Улучшается состояние боевой подготовки. Так, например, в батальоне, которым командует капитан Слесарев, беспартийный, имеется $100 \%$ успеваемость по тактике, 
огневой и строевой подготовкам, имеется 232 курсанта - отличника. Во втором батальоне, которым командует старший лейтенант Сабиров кандидат ВКП/б/ общая успеваемость в батальоне 99,48\%, курсантов отличников более 50\%. В остальных подразделениях несколько хуже по боевой подготовке, но она изо дня в день улучшается и число курсантов - отличников увеличивается.

Таковы, некоторые итоги по выполнению приказа НКО № 307. По плану политотдела 11 декабря 1942 года состоялось собрание командиров коммунистов и комсомольцев с вопросом «Реализация приказа НКО № 307». Докладывал заместитель начальника училища по политчасти интенданта 1 ранга товарищ Самойленко. ${ }^{15}$

Одним из важнейших аспектов работы любой военной организации как прежде, так и ныне, является сохранение военной тайны (защита государственной тайны). Ниже представлено донесение, полностью отображающее данную работу в училище.

Заместителем начальника политического отдела Рязанского пулемётного училища батальонным комиссаром Заворотищевым на имя начальника политического управления МВО бригадного комиссара Миронова в декабре 1942 года в донесении о сохранении военной тайны в связи с директивой начальника Главного политического управления РККА № 0464 говорилось, что с данной директивой были ознакомлены все политработники. Работники политотдела, заместители командиров батальонов, секретари партийных и комсомольских организаций, а также преподаватели политической подготовки.

После того, как все политработники были ознакомлены с директивой № 0464, по всем подразделениям были проведены целый ряд бесед с курсантами и командирами на тему «О сохранении военной тайны» и «О бдительности». В беседах особенно обращалось внимание на содержание писем, отправляемых родным и знакомым и на содержание разговоров с населением.

Подобные беседы проводились и до получения директивы № 0464, но с получением этой директивы беседы на эту тему оживились в большей степени.

В своих политдонесениях в политотдел заместители командиров батальонов по политчасти пишут исключительно по вопросам политико-морального состояния личного состава подразделений, дисциплинарной практики, партийно-политической и культурно-массовой работе, боевой и политической подготовке, где главным образом сообщается успеваемость по дисциплинам, показываются курсанты-отличники, передовые подразде- ления, с указанием командиров. Что касается данных, не подлежащих оглашению, как например: количество личного состава, количество и состояние техники, местонахождения подразделений, то это в политдонесениях не сообщалось и не сообщается.

Причём политдонесения, которые пишут заместители командиров батальонов для политотдела, вручаются ими самими лично начальнику или заместителю начальника политотдела.

С самого начала деятельности училища политотдел не имел и сейчас не располагает фактами разглашения военной тайны. Но имелись такие случаи:

1. В связи с организацией в августе 1942 года пулемётного училища, население города Касимова, уже об этом знало.

2. Курсант Корнилов из 1 батальона, член ВЛКСМ, в своём письме знакомой пытался сообщить о своём плохом настроении и о том, что его однажды в воскресенье плохо накормили. Это письмо было задержано.

3. Вольнонаёмные и некоторые военнослужащие училища по вызову к телефону сообщали: «Слушает пулемётное училище», вместо: «Слушает воинская часть».

4. Писались отношения в гражданские организации со штампом «Рязанское пулемётное училище».

5. В начале некоторые курсанты своим родным сообщали полностью адрес училища, вместо номера почтового ящика.

6. В клубе на доске показателей отличников вместо литеров были указаны номера батальонов.

Все указанные случаи имели место в начале организации училища, в настоящее время подобных фактов не имеется. ${ }^{16}$

Большая работа проводилась первичными комсомольскими организациями батальонов и первичной комсомольской организацией штаба училища, донесения которых ежемесячно представлялись в политотдел училища. Так в протоколе № 4 заседания бюро штабной парторганизации Рязанского пулемётного училища от 12 декабря 1942 года на повестке дня стоял вопрос о заслушивании отчёта комсомольской организации штабной группы. Секретарь комсомольской организации данной группы Митьков в своём выступлении констатировал следующее: «Работа, которую вела комсомольская организация состояла в следующем: проводилась читка газет, проведена лекция и беседа по работе среди вольнонаёмного состава училища на тему «Военное обучение», которую проводил комсомолец старший лейтенант

15 ЦАМО. Ф. 60067. Оп. 35134. Д. 22. Л. 47, 48, 4806, 49.

16 ЦАМО. Ф. 60067. Оп. 35134. Д. 22. Л. 44, 44об. 
Шершаков». ${ }^{17}$

С момента формирования училища и до окончания 1942 года в училище были случаи смерти и гибели военнослужащих. Исключён из списков училища рядовой хозяйственной роты Самшорин Ф. Д., умерший в городской больнице от болезни 8 октября 1942 года. ${ }^{18}$ Погиб при исполнении служебных обязанностей в ночь на 23 октября 1942 года курсант 5-й роты Девятов Сергей Васильевич. ${ }^{19}$ Родился в 1924 году, призванный в августе 1942 года Гаврилово-Посадским РВК Ивановской области. Имел образование 9 классов. ${ }^{20}$ Покончил жизнь самоубийством 14 ноября 1942 года курсант 20-й роты Мурашов Евгений Алексеевич, 1924 года рождения. Имел образование 7 классов, до поступления в училище работал электромонтёром в Ленинграде. ${ }^{21}$ Умер в санчасти от воспаления лёгких 26 ноября 1942 года курсант Новоуспенский Игорь Иосифович 1924 года рождения. Имел образование 8 классов. Призван ив августе 1942 года Просницким РВК Кировской области. ${ }^{22}$

Исключён из списков части курсант 4-й роты Пикорилов О.И., умерший 27 декабря 1942 года в городской больнице. ${ }^{23}$

Из представленных выше данных видно, что трое военнослужащих умерли по причине болезни. Меры медицинского обеспечения были предусмотрены приказом по училищу № 21 ещё 30 августа 1942 года, в котором устанавливалось время приёма санчастью больных курсантов с 13:00 до 14:30 часов ежедневно. Кроме того, был установлен порядок приёма, согласно которому больные регистрировались в канцеляриях рот и журналы регистрации к указанным выше часам приёма передавались дежурному врачу. ${ }^{24}$ Несмотря на принятые меры смертей военнослужащих не удалось избежать по причинам слабого контроля командиров за состоянием здоровья своих подчинённых, неудовлетворительного медицинского обеспечения, плохого снабжения военнослужащих.

Своеобразным подведением итогов политико-воспитательной работы в Рязанском пулемётном училище за 1942 год является донесение от 30 декабря 1942 года секретаря партийной комиссии Рязанского пулемётного училища капитана Султанова на имя секретаря партийной комиссии политического управления МВО о проделанной работе с 6 сентября по 30 декабря 1942 года. В нём говорилось:

При политотделе Рязанского пулемётного училища города Касимова организовано первичных партийных организаций - 7, низовых - 4, из них батальонных - 5, ротных - 4, при штабе училища - 1, при хозяйственной роте - 1. Всего коммунистов 124 чел., из них командиров 105 чел., курсантов 11 чел., вольнонаемных - 8 чел.

За это время проведено 12 заседаний партийной комиссии, где заслушивали 9 докладов первичных партийных организаций по вопросам:

1. О работе среди кандидатов в члены ВКП/б/ и членов ВЛКСМ;

2. О работе парторганизаций и помощи вступающим в ряды ВКП/б/;

3. Об авангардной роли коммунистов в боевой политической подготовке;

4. О партдисциплине;

5. О выполнении коммунистами приказов товарища Сталина 130, 227;

6. О работе парторганизаций с коммунистами, комсомольцами средними и младшими командирами;

7. О повышении идейно-политического уровня коммунистов;

8. О выполнении решения партийной комиссии от 30 сентября 1942 г;

9. О работе парторганизаций штаба училища;

10. Принято в партию всего 19 человек, из них членов ВКП/б/ 3 человека, кандидатами в члены ВКП/б/ 16 человек. Из принятых кандидатов в члены ВКП/б/ 15 человек приняты из числа комсомольцев отличников боевой и политической подготовки. Желающих вступить в партию всего 49 человек, из них 30 материалов находятся в стадии оформления /посланы запросы Райкомам ВКП/б/ с просьбой прислать рекомендации/. Затруднение по части роста партии заключается в том, что училище вновь организовано, как командиры, так и курсанты, съехавшиеся из разных областей, друг друга не знают и не могут дать рекомендаций. Делаются запросы в Райкомы ВКП/б/ на которые они очень долго не присылают рекомендаций;

11. Рассмотрено персональных дел 29 , из них на членов ВКП/б/ 11, на членов ВКЛСМ 18, по характерам рассмотренных дел выглядит следующее:
17 ЦАМО. Ф. 60067. Оп. 35134. Д. 23. Л. 14 об. - 16.

18 ЦАМО. Ф. 60067. Оп. 35135. Д. 7. Л. 53.

19 Там же, Л. 70.

20 ЦАМО. Ф. 60067. Оп. 35135. Д. 2. Л. 4206., 43.

21 Там же, Л. 13306., 134.

22 Там же, Л. 50об., 51.

23 ЦАМО. Ф. 60067. Оп. 35135. Д. 7. Л. 118.

24 Тамже, Л. 19. 
1) нарушение воинской дисциплины - 25;

2) не тактичное поведение коммунистов - 2;

3) не своевременная уплата членских и партийных взносов - 1;

4) утеря комсомольских билетов - 5;

5) убийство курсанта членом ВЛКСМ Веричем - 1;

6) как арестованного члена ВЛКСМ Комарова - 1;

7) дезертирство - 1.

По рассмотренным персональным делам принято следующее решение:

1. Исключено из комсомола 7 человек:

1) Плешаков И. В. за пьянку и хищение 21 кг мыла;

2) Верич Н.М. за убийство курсанта;

3) Вакуновский В.А. за пьянку и нарушение воинской дисциплины;

4) Баталов И.С. за пьянку и самовольные отлучки;

5) Радюшин К.И. за дезертирство;

6) Комаров В.И. как арестованный:

7) Кузнецов за пьянку и неоднократное нарушение воинской дисциплины.

2. Объявлен строгий выговор - 8 человек;

3. Объявлен выговор на - 6 человек;

4. Предупреждено - 7 человек;

5. Поставлено на вид 1 человек.

Все члены партийной комиссии принимают активное участие в проводимых ею мероприятиях.

Партийная комиссия все свои мероприятия под руководством начальника политотдела майора товарища Ватутина выполнила.

Кроме того, излагалась просьба к окружной партийной комиссии о снабжении руководящими партийными директивами и положением о партийной комиссии. ${ }^{25}$

Год 1942-й стал для училища годом его создания и становления. За четыре с половиной месяца своей работы в 1942 году училище столкнулось с большим количеством всесторонних проблем различного характера. Несмотря на это и благодаря самоотверженному труду личного состава, в том числе в большей степени в области политико-воспитательной работы училище продолжило успешно функционировать. Ведущая и движущая роль в деле воспитании и подготовки офицеров-пулемётчиков отводилась ВКП/б/ и ВЛКСМ, которые со своей задачей справились и при их непосредственном участии было выпущено 3336 офицеров, 8 из которых стали Героями Советского Союза.

\section{ПРИНЯТЫЕ СОКРАШЕНИЯ}

1. ЦАМО - Центральный Архив Министерства Обороны

\section{ЛИТЕРАТУРА}

1. ЦАМО. Ф. 60067. (Рязанское пулемётное училище) Краткая историческая справка.

2. ЦАМО. Ф. 60067. Оп. 35134. Д. 22. Л. 1, 2, 3, 11, 12, 1206., 25, 26, 2606., 44, 4406., 46, 47, 48, 4806., 49, 54, 55, 5506.

3. ЦАМО. Ф. 60067. Оп. 35135. Д. 4. Л. 243.

4. ЦАМО. Ф. 60067. Оп. 35134. Д. 23. Л. 1-3 с 06., 1406. -16.

5. ЦАМО. Ф. 60067. Оп. 35135. Д. 7.Л. 19, 53, 58, 5906, 60, 70, 90, 9106., 118.

6. ЦАМО. Ф. 60067. Оп. 35135. Д. 2. Л. 4206., 43, 5006., 51, 13306., 134.

с Л Ларин Геннадий Владимирович (larin191975@yandex.ru). 